\title{
Dental Caries and Fluoretation of Public Supply Waters: The Reality of Northern Brazil
}

\author{
Livianny S. B. Cunha, José F. F. Gomes, and Rosiane F. N. Rosa
}

ABSTRACT

The aim of this study is to carry out a literature review covering conceptual and epidemiological aspects associated with dental caries disease in Northern Brazil. A survey of specialized literature was carried out in the SciELO, PubMed, Virtual Health Library, and Google Scholar databases, using the following descriptors: fluoride, fluoridation, dental caries, and epidemiology. Dental caries is a chronic and multifactorial disease, influenced by the human diet and by social, economic, cultural, and behavioral determinants. There is a disparity in oral health when comparing the poorest regions of Brazil, with a lack of fluoridation of water for human consumption.

Keywords: Dental Caries, Epidemiology, Fluoride, Fluoridation.
Published Online: September 15, 2021

ISSN: $2684-4443$

DOI: $10.24018 /$ ejdent.2021.2.5.92

Livianny. S. B. Cunha*

São Lucas University Center, Porto Velho, Rondônia, Brazil.

(e-mail: 1sbcunha06@gmail.com)

José F. F. Gomes

São Lucas University Center, Porto

Velho, Rondônia, Brazil

(e-mail: gomesjff@ gmail.com)

Rosiane F. N. Rosa

São Lucas University Center, Porto

Velho, Rondônia, Brazil.

(e-mail:rosiane_nogueira@hotmail.com)

*Corresponding Author

\section{INTRODUCTION}

Studies carried out in the last decades have revealed, for different age groups, a decrease in the prevalence of oral diseases in Brazil. This is mainly due to technological advances and innovation in the field of dentistry, as well as due to the increased demand for dental treatments [1] and the development of public health policies promoted by the municipalities [2]. Regarding dental caries, in developed and developing countries, as is the case in Brazil, the reduction of this disease in recent decades is due, in large part, to the wide use of fluoridated toothpaste [3]. However, the socioeconomic condition is a persistent factor and is responsible for the maintenance of oral problems, which can result in tooth loss [4]. In this sense, it is noticed that some factors, including income, housing, food, education, among others, have a significant influence on the population's oral health pattern [5].

The lack of access to dental services is also considered one of the determining factors when considering the prevalence of oral conditions (e.g., dental caries and periodontal disease). As a consequence, significant damage arises both in the physiological (functional) aspects and in the aesthetic and psychosocial issues [6]. Dental caries considered the main oral disease that affects the Brazilian population, can be characterized as a multifactorial and complex disease, in which several environmental and behavioral characteristics interact [7]. In biochemical terms, tooth decay is the result of an imbalance between the processes of demineralization and remineralization of the tooth [8], in which there is a mineral loss at the interface between the tooth and the dental biofilm. The evolution of this disease, if it is not paralyzed, will result in the progression of tissue destruction of the dental element [9], which may result, in extreme cases, in tooth loss.

In this sense, in order to combat the dynamic and complex disease of dental breakdown, fluoride-containing products are used worldwide. This is considered the agent responsible for the prevention of said oral disease, as well as for the treatment of it in its early stages [10], [11]. Fluoride provides greater resistance to the enamel surface through its continuous presence in the oral environment, acting topically (locally), interfering with the demineralization and remineralization processes that occur regularly in dental elements. Therefore, the beneficial effects of fluoride are due to its frequent presence in the oral cavity, in small amounts, throughout the individual's life [12].

In order to provide the presence of fluoride in the oral environment, different means of using fluoride are used, among which are mentioned mainly: individual means that include fluoridated toothpaste, fluoridated solutions for daily rinsing (sodium fluoride solution $\mathrm{NaF}$ a $0.05 \%$ ), and fluoride medications; professional means that cover products for professional application such as fluorinated gels and varnishes; and collective means that include fluoridated solutions for weekly mouthwash $(0.2 \% \mathrm{NaF}$ sodium fluoride solution) and fluoridated water supply [13], [14]. The fluoridation of public water supply is pointed out in several studies as the best collective method of exposure to fluoride, resulting mainly from its high effectiveness, low cost, and high frequency of consumption [10], [15], [12]. 
In addition, in order to prevent tooth decay, fluoridated water is considered the most significant method of using fluoride in public health, as it is extremely safe and comprehensive, benefiting a large part of the population that uses it [12]. In communities with continuous exposure to fluoridated water, for example, and with adequate fluoride levels, there is an expectation of a reduction in the prevalence of dental caries by 50 to $65 \%$ [16], thus evidencing its proven anti-caries effect and its public relevance. Therefore, the objective of this research is to carry out a literature review addressing from conceptual and epidemiological aspects associated with dental caries disease in Northern Brazil to the fluoride anti-caries mechanism of action and the coverage of public water supply fluoridation in that region, without intending to exhaust these matters.

\section{MATERIALS AND METHODS}

The present study consists of a bibliographic search in which a specialized literature survey was carried out in the following databases: SciELO, PubMed, Virtual Health Library (VHL) and Google Scholar. Official documents from the Ministry of Health were also consulted, as well as Brazilian regulations regarding the fluoridation of public water supply. For this search, the following descriptors were used, in Portuguese and English: fluoride, fluoridation, dental caries, and epidemiology.

This study excluded articles that were not related to the topic addressed or that did not match the previously mentioned descriptors. Therefore, data sources between the periods from 1983 to 2019 were included in the present study.

In this research, it was proposed to discuss two topics that were addressed separately: "dental caries", "fluorine" and "fluoridation of public water supply". For each of these sections, studies were included that would allow discussion about the etiology / epidemiology of caries disease, as well as the fluoridated water coverage, especially in the Northern region of the country.

\section{RESULTS AND DISCUSSION}

\section{A. Dental Caries - Etiology}

Dental caries is a chronic and multifactorial disease, whose lesions, in most cases, progress slowly. This disease initially manifests itself through an active white ax reversible stage - until an advanced stage characterized by destruction of the dental structure, mainly in the absence of adequate treatment [8]. It is strongly influenced by the contemporary human diet, resulting from changes in eating habits since primitive times. As a consequence of this change in the eating pattern, a physical-chemical imbalance was triggered by nature itself, with the consequent demineralization and remineralization developed in the oral environment, which resulted, in turn, in the occurrence of lesions in the tooth structure [17].

Several studies have shown the importance of etiological factors in the development of diseases, however, that many of these factors are understood only considered as key factors in the emergence of health diseases [17]-[19]. Among the etiological aspects of dental caries disease, the necessary factors for the emergence of caries (dental biofilm), the determinants (exposure to sugar), and modulators (biological and social) can be cited [20]. In view of this, because dental caries is a very complex and behavioral disease easily influenced by modifying factors, several studies show the complexity of explaining the occurrence of this disease in the population [17].

The saliva considered an intrinsic factor that has the ability to neutralize the acids produced in the oral environment, resulting from the action of bicarbonate and phosphate ions. In addition to this neutralization function, it works by promoting cleaning, lubrication and also having antibacterial action, inhibiting the enzymatic complex (such as histatin) that promotes the reduction of the metabolic activity of bacteria [17], [21], [22]. There are relationships between dental biofilm and the multiple biological factors that interfere in the process of developing caries lesions [21]. Certain characteristics, such as the production of acids (resulting from the fermentation of carbohydrates present in the oral environment) and the ability of acidogenic bacteria to adhere to dental structures are important factors in the appearance of carious lesions, but they are not the only factors that contribute to the development of the referred disease [17].

The diet, for example, contributes significantly to the emergence of dental caries disease, since it is on the cariogenic substrate (diet) that the activity of microorganisms occurs, since they need to carry out energy metabolism, thus enabling their own survival [22]. The time factor has a very significant and strong correlation, which can be explained by the fact that the process of formation and development of dental caries is something continuous and that requires a certain period of time to result in a mineral loss (demineralization) of the dental elements [18]. In this context, the factors that modulate the disease include social, economic, cultural, psychological, behavioral factors, as well as access to health services [20]. Thus, socioeconomic differences, education level, income, way of life, and access to health and leisure, are strongly associated with the health standards of the populations. High socioeconomic status has, in most cases, a better oral health condition when compared to low-income people, thus having a strong correlation between social class and the presence of dental caries [23].

As a consequence of the influence of modulating factors on the prevalence of caries, it is proven that age, sex, and family patterns are factors that can, for example, directly influence the CPO-D index (decayed, lost, and filled teeth index) and ceo-d (decayed, exfoliated and filled primary teeth index) [23]. The prevalence of dental caries in children from public schools was higher when compared to children from private schools, as well as the CPO-D / ceo-d indexes, with the type of school being a sensitive variable to discriminate between different oral health conditions [24]. In this context, when considering the social determinants of health, it is essential to verify the context to which the populations are exposed. Above all, the development of public policies and health actions directed at society should be considered, with efforts being directed mainly to people 
in conditions of vulnerability [25].

\section{B. Dental Caries - Epidemiology in the North of the Country and its national comparison}

Several studies have shown a reduction in the prevalence of dental caries disease, expressed by the values of the ceod/CPO-D indexes over the period between 1986 and 2010 . Among the factors responsible for the referred decline are increased access to fluoridated water, the increasingly constant use of fluoridated toothpaste, and preventive actions to promote oral health carried out by local programs [2], [26], [27]. Historical surveys pointed to a $70 \%$ reduction in the CPO-D index for children aged 12 years, from 1986 to 2010, dropping from 6.7 to 2.1 teeth with caries experience. In the same period, it is also noted, for the same age group, that the prevalence of children with decayed teeth dropped from $96 \%$ to $56 \%$. In the evaluation of dental caries in adolescents and adults, there was a reduction of the CPO-D index of more than $67 \%$ in the age group of 15 to 19 years, between the period from 1986 to 2010. When considering the "decayed" component, in this studied period, the reduction reaches almost $66 \%$. It is inferred that, in addition to having a lower prevalence and severity of dental caries in adolescents, it is being treated in a more conservative manner. On the other hand, between 1986 and 2010 , in the age group of 35 to 44 years, the reduction was $26 \%$. For "filled" teeth, which made up $16 \%$ of the index in 1986 , it rose to $44 \%$ in 2010 , just as the "lost" component went from $66 \%$ in 1996 to $45 \%$ in 2010 . It is suggested that, in addition to having a lower prevalence of caries in adults, these are being treated more adequately [28].

About the epidemiological picture pointed out by the National Survey of Oral Health - SB Brazil Project 2010 $46.6 \%$ of the Brazilian population aged 5 years is free of caries [16]. In these results, similar values are presented among populations of 12 years, which show a proportion of $43.5 \%$ of children free of caries. In the age groups 15 to 19 , 35 to 44 , and 65 to 74 years old, the percentages were, respectively, $23.9 \%, 0.9 \%$, and $0.2 \%$. So too, when assessing the oral health conditions of the population, Brazil is characterized by intense regional diversity. In this sense, the South and Southeast regions stand out for having better patterns in the distribution of the prevalence of dental caries in certain age groups. In contrast, in comparison to other regions of the country, the North region shows the worst prevalence in the records of ceo-d and CPO-D for the ages of 5 years, 12 years, and 15 to 19 years. When considering the national percentages, it is clear that individuals aged 5 years, 12 years, and 15 to 19 years, with ceo / CPO equal to zero, have the following percentages, respectively: $46.6 \%$; $43.5 \%$, and $23.9 \%$. In turn, the North of the Country reveals, for the same previous age groups (in the same sequence) the following values of caries-free individuals: $33.9 \%, 28 \%$, and $12.1 \%$.

Furthermore, when evaluating the data from the SB Brasil 2010 survey involving the interior cities of the North region of the country and its comparison with the interior cities of the other regions of Brazil, the percentages show that not only the large urban centers (capitals) of the North Region present the worst indexes in comparison to other capitals of the country, just as this is a noticeable reality in the interior cities of the North region when compared to the interiors of the other regions of the country. Thus, the ceo-d / CPO-D index, in the ages of 5 years, 12 years, and in the age group between 15 to 19 years, present significant results that show the high experience of dental caries in the North region, when compared to the other regions of Brazil [16]. From these results, it can be seen that the performance of the North region, in relation to the experience of dental caries, is, for the most part, below the values observed for other regions of the country. Among the explanatory factors for the preferred health disparities, oral health can be cited as the socio-economic level of the population of that locality, characterized by high rates of poverty and poor socioeconomic indicators. In addition, disparities in relation to dental caries in Northern Brazil are strongly associated with the scarcity of public investment in a comprehensive method of using fluorine, which is the fluoridation of public water supply [2]. Furthermore, in the North of the country, for example, there are few municipalities that have a public supply network with fluoridated water. Although there are studies that prove the reduction in the prevalence of dental caries when fluoride the water of public supply, this is still a distant reality for the North of Brazil [12].

\section{Fluorine and Its Anti-caries Mechanism of Action}

The important effect of fluoride in preventing cariogenic injuries was discovered at the beginning of the last century. In this sense, his mechanism of action, regardless of the means of use, is always the same, that is, it is topical (local). Therefore, the fluoride ion must be present in the oral cavity, interfering in the processes of demineralization and dental remineralization, in which the liquid mineral loss is reduced since part of the lost minerals is answered again in the dental structure [29], [14]. In the past, it was believed that fluoride incorporated into the mineral structure of teeth would enable less dental solubility, even increasing resistance to bacterial acids [14]. However, there is currently a consensus in the literature that the predominant effect of fluoride is not systemic, altering the structure of enamel and dentin. It must be present continuously in the oral environment, where sugar is exposed and where fluoride interferes with its anti-caries mechanism [29]. Therefore, although fluoride can interfere in the development processes of caries lesions, it is not able to prevent the development of these lesions, as it cannot prevent the formation of dental biofilm on the dental surface [30].

Therefore, in the place where fluoride is most needed, that is, at the interface between tooth and biofilm, the presence of this ion reduces demineralization and activates dental remineralization, thus fulfilling its anti-caries effect. In this context, faced with the production of acids (with a consequent drop in $\mathrm{pH}$ ), the tooth ends up suffering demineralization of its enamel. However, if there is a fluoride ion in the oral cavity - with a $\mathrm{pH}$ greater than $4.5-$ at the same time that the hydroxyapatite dissolves, fluorapatite is formed. However, this mineral is about 10,000 times less soluble than hydroxyapatite. As a consequence, the net result of this process is a reduction in the dissolution of enamel and dentin. Thus, the indirect effect of reducing enamel and dentin demineralization when the $\mathrm{pH}$ drops is, on the other hand, offset by the effect on 
remineralization when the $\mathrm{pH}$ increases. For this reason, the use of fluoridated toothpaste and the fluoridation of public water supply - individual and collective means of fluoride use, respectively - constitute the main means that increase the concentration of fluoride ions in the oral cavity, resulting from regular exposure to low concentrations of it [30]. Fluoride dentifrice is considered the most rational way to use fluoride, as it associates the disorganization of dental biofilm with exposure of the oral cavity to this ion. On the other hand, fluoridated drinking water is a universal means of using fluorine that benefits individuals who ingest it directly or those who consume it indirectly through, for example, food prepared with it. Remembering that fluoridated water only benefits people who are ingesting it continuously [14].

In the last decade of the 20th century and the first decade of the 21 st century, important oral health interventions were implemented and expanded throughout Brazil. Among them, the following stand out: addition, from 1988, of fluoride compounds to a toothpaste marketed in the country; fluoridated public water supply; dental care in the public health system; and decentralization of the Brazilian health system, expanding population preventive strategies [31]. Several studies have shown that the first two factors (fluoridated toothpaste and fluoridated water) are considered to be the main responsible for the decline of dental caries disease in Brazil [32], [33]. Despite this beneficial characteristic of fluoride, this ion can bring side effects to the human body, depending on the absorbed dose and the type of exposure. Thus, the classification appears in the acute or chronic intoxication, resulting from systemic effects of fluoride. Acute toxicity is characterized by an excessive intake of a high amount of fluorine, in a single dose, which can trigger milder symptoms (stomach upset and vomiting) to death. In turn, chronic intoxication, which is dental fluorosis, represents an effect of chronic exposure to fluoride during tooth development, characterized by a defect in the formation of the enamel whose aesthetic compromise depends on the dose-response effect [14], [31]-[33].

\section{Fluoridation of Public Water Supply - Legal and General Aspects}

Public health water fluoridation is considered, in public health, an extremely effective means of preventing dental caries, as it is safe, low-cost, and affects a large portion of the population (in this case, only individuals residing in areas that offer this service). collective means of fluoride use) [12]. Fluoridated water is, therefore, considered an efficient method in promoting oral health in the Brazilian population, being one of the factors responsible for the decline of dental caries in the country [15], [30], [12], as mentioned in the sub-item "fluoride and its anti-caries action mechanism". Given the importance of public water supply fluoridation, scientific research has sought to understand the political and legal aspects linked to this collective means of using fluoride, just as they have investigated general aspects associated with this public health benefit, with issues that they involve the per capita cost by year of fluoridation per inhabitant, the monitoring of fluoride in fluoridated waters, the optimal concentration of fluoride in water, among others.
In this sense, Brazilian legislation determines, for example, through Federal Law No. 6,050, of May 24, 1974, mandatory water fluoridation in locations that have a treatment plant. This law is regulated by Federal Decree No. 76,872 , of December 22, 1975, which provides for mandatory fluoridation. Thus, for the aforementioned decree, it is established that the Ministry of Health is the body responsible for the norms and standards for the fluoridation of public water supplies throughout the national territory. In this sense, and in order to promote regulation in all Brazilian municipalities, it sets out mandatory conditions, establishes methods of analysis and procedures for the fluoridation of public water supply, even in places where there are no Water Treatment Plants. Water. However, it determines the minimum and maximum permitted fluoride ion concentrations and the technical and economic feasibility of the measurement, as well as the respective dental nosological picture of the population. In turn, Ordinance No. 635 of the Ministry of Health, of December 26, 1975, approves norms and standards on water fluoridation, in view of Law No. 6,050 of 1974. In that Ordinance, the concentration of the fluoride ion is determined to be used - considering the maximum annual temperatures by region - as well as the recommended compounds, in order to make effective implantation of the fluoridation of public water supply [10].

Ordinance No. 2,914, of December 12, 2011, issued by the Ministry of Health, provides for the control and surveillance procedures of the quality of water for human consumption, as well as its drinking water standard. In this sense, the said Ordinance provides information regarding the quality control of fluoridated water, in values acceptable for human consumption, whose maximum permitted content for the fluoride ion is 1.5 milligrams per liter of water $(\mathrm{mg} / \mathrm{L})$ [34]. Despite the Federal legislation stating the maximum value of $1.5 \mathrm{mg} / \mathrm{L}$ of fluoride ion in public water supply, there are Brazilian states that limit this value through State Decrees. According to the study by Frazão et al. [2], taking into account the temperature variable, the authors stated that the adequate fluoride content recommended for most Brazilian municipalities ranges from 0.6 to $0.8 \mathrm{mg} / \mathrm{L}$, which is much lower than the current federal recommendation. However, the level of fluoride to be added to the water must be determined according to the average annual temperature in the region. This is due to the fact that in countries with temperate climates (with lower annual temperatures), the daily water intake is lower than in tropical countries, such as Brazil. In that country, whose annual temperatures are high, the daily consumption of water is consequently increased.

Therefore, considering the average annual temperature defined for tropical climate, the optimal concentration of 0.7 ppm of fluoride (0.6-0.8 ppmF) was established as being ideal for most regions of Brazil [35]. In addition, there are studies that prove that the volume of fluoridated water ingested by a given population is totally dependent on other local peculiarities, in addition to temperature, which includes: socioeconomic conditions, access to fluoridated products, dietary habits, among others. In this sense, there is a technical consensus issued by the Collaborating Center of the Ministry of Health, in Oral Health Surveillance, of the 
Faculty of Public Health of the University of São Paulo, in 2011, which classifies the fluoride levels of public water supply based maximum benefit of caries prevention and minimal risk to individuals' health [12]. Thus, recognizing that the fluoridation of public water supply is an important factor in the decline in the prevalence of dental caries in Brazil, therefore, in addition to being maintained, it must be monitored, so that the amount of fluoride is kept within the standards of security for the health of the population and that it plays its anti-caries role.

\section{E. Fluoridation of Public Water Supply - Coverage of Water Fluoridation in the North of the Country}

In Brazil, the optimum levels of fluoride ion in public water supply for human consumption, which bring the maximum benefit in preventing dental caries and the minimum risk to the health of the population, vary between 0.6 and $0.8 \mathrm{mg} / \mathrm{L}$ [15]. Among the main parameters in determining water quality, the concentration of fluoride for human consumption stands out, as it represents an important indicator of protection or risk to oral health. Thus, in a national scenario, in a period between 2010 to 2015 and for levels of percentage distribution in municipalities with more than 50 thousand inhabitants, the South region of Brazil stands out with percentages above $70 \%$ of its municipalities with the supply of fluoridated waters suitable for human consumption, with the presence of effective monitoring. On the other hand, in the northern region of Brazil, this curve is reversed, presenting almost $90 \%$ of its municipalities without fluoride in the waters available for consumption [36]. In this context, there is a higher CPO-D index for the northern region of Brazil compared to other regions [16-37]. When evaluating only the North region of the country, it is noticed that there is a significant number of municipalities without the coverage of fluoridation of public water supply [38]. Thus, according to the study by Pinheiro et al. [39], only twelve have their population covered by fluoridated water, namely: Manaus (AM), Cametá (PA), Dom Eliseu (PA), Oriximiná (PA), Paragominas (PA), Ariquemes (RO), Jaru (RO), Vilhena (RO), Boa Vista (RR), Araguaína (TO), Gurupi (TO) and Palmas (TO).

In general, the water fluoridation coverage characteristic is defined by the geographic location of the aforementioned locations. In this sense, this collective means of using fluoride in these municipalities is justified, due to the proximity to urban agglomerations, in which access to basic services (for example, health care and the monitoring of quality surveillance control agencies water) is facilitated, added to the benefits provided by the infrastructure and accessibility constraints. Thus, it is also understood why the decentralization of the physical structure, mainly of the laboratories responsible for monitoring the quality of public water supply, for the most populous states - Amazonas and Pará [39]. In the same study, the State of Rondônia, with an estimated population for 2014 that exceeds one million inhabitants, presents only $8.8 \%$ of its population with fluoridated water. In this scenario, only the municipalities of Ariquemes, Jaru and Vilhena have coverage by fluoridated water, in a proportion of $67.4 \%, 33.5 \%$ and $1.4 \%$ of the population, respectively, receiving the referred benefit. In turn, the city of Porto Velho, which concentrates most of the population of Rondônia (approximately 494 thousand inhabitants), does not have fluoridated public water supply.

\section{FINAL CONSIDERATIONS}

Dental caries is a chronic, complex, and multifactorial disease. Thus, the necessary factors (dental biofilm), determinants (exposure to sugar), and modulators (biological and social) are considered, in a comprehensive way, the etiological aspects associated with the development of caries disease.

In order to combat this oral disease, reducing its prevalence in the population, the following measures can be adopted mainly: access to fluoridated water; constant use of fluoridated toothpaste; and oral health promotion developed by local health programs.

The North Region, when compared to other regions of Brazil, as demonstrated by national epidemiological studies, is characterized by a high disparity in oral health. Among the factors responsible for these differences, especially in relation to dental caries, the following stand out: socioeconomic level of the majority of the northern population; development of public oral health policies developed at the municipal and state levels; and scarcity of public investment in a comprehensive method of using fluoride, such as fluoridated water.

Fluoridation of public water supply is considered an extremely effective means of preventing dental caries since it is a comprehensive method of using fluoride, as it affects a large portion of the population that is exposed to this benefit. In the Northern Region of Brazil, it is evident that a significant number of municipalities do not have coverage of their water fluoridation.

\section{REFERENCES}

[1] Ainamo, J. The monitoring process and its importance for achievement of the global goals for oral health by the year 2000. Int Dent J., v. 33, n. 1, p.79-89, 1983.

[2] Frazão, P., Santos, C. R. I., Benicio, D. E. D. A., Marques, R. A. A., Benicio, M. E. D. A.; Cardoso, M. A., Narvai, P. C. Cárie dentária em escolares de 12 anos de idade em município sem água fluoretada na Amazônia Ocidental brasileira, 2010. Epidemiol. Serv. Saúde, v. 25, n. 1, p. 149-158, 2016.

[3] Cury, J. A., Tenuta, L. M. A. Riscos do uso do Dentifrício Fluoretado na Prevenção e Controle de Cárie na Primeira Infância. Rev. Fac. Odontol. Porto Alegre, v. 53, n. 3, p. 21-27, 2012.

[4] Antunes, J. L., Jahn, G. M., Camargo, M. A. Increasing inequalities in the distribution of dental caries in the Brazilian context. Community Dent Health. v. 22, n. 2, p. 94-100, 2005.

[5] Silva, J. V., Machado, F. C. A., Ferreira, M. A. F. As desigualdades sociais e a saúde bucal nas capitais brasileiras. Ciência \& Saúde Coletiva, v. 20, n. 8, p. 2539-2548, 2015.

[6] Souza e Silva, M. E., Villaça, E. L., Magalhâes, C. L., Ferreira, E. F. Impacto da perda dentária na qualidade de vida. Ciência \& Saúde Coletiva, v. 15, n. 3, p. 841-850, 2010.

[7] Maltz, M., Tenuta, L. M. A., Groisman, S., Cury, J. A. Cárie dentária: conceitos e terminologia. In: Kriger, L., Moysés, S. J., Moysés, S. T. (Org.) Cariologia: Conceitos básicos, diagnóstico e tratamento não restaurador. São Paulo: Arts Médicas, 2016, Cap 1, p. 11-16.

[8] Mangueira, D. F. B., Passos, I. B., Pereira, A. M. R. C., Oliveira, A. F. B. Cárie e erosão dentária: uma breve revisão. Odontol. Clín. Cient., Recife, v. 10, n. 2, p. 121-124, 2011

[9] Pitts, N. B. Diagnostic tools and measurements- impact on appropriate care. Community Dent Oral Epidemiol, v. 25, p. 24-35, 1997.

[10] Ramires, I., Buzalae, M. A. R. A fluoretação da água de abastecimento público e seus benefícios no controle da cárie dentária: 
cinquenta anos no Brasil. Ciência Saúde Coletiva, v. 12, n. 4, p. $1057-$ 65, 2007.

[11] Soares, G. G., Souza, P. P., Purger, F. P. C., Vasconcellos, A. B., Ribeiro, A. A. Métodos de detecção de cárie. Revista Brasileira de Odontologia, v. 69, n. 1, p. 84-9, 2012.

[12] Garbin, C. A. S., Santos, L. F. P., Garbin, A. J. I., Moimaz, S. A. S., Saliba, O. Fluoretação da água de abastecimento público: abordagem bioética, legal e política. Rev. Bioét., v. 25, n. 2, p. 328-37, 2017.

[13] Brasil. Ministério da Saúde. Secretaria de Atenção à Saúde. Departamento de Atenção Básica. Guia de recomendações para o uso de fluoretos no Brasil - Brasília: Ministério da Saúde, 54p, 2009.

[14] Tenuta, L. M. A., Cury, J. A. Evidências para o uso de fluoretos em Odontologia - Parte II: Meios de usar fluoreto em odontologia. Jornal da $A B O$, p. 25-26, 2008.

[15] Frazão, P., Peres, M. A., Cury, J. A. Qualidade da água para consumo humano e concentração de fluoreto. Rev Saúde Pública, v. 45, n. 5, p. 964-73, 2011.

[16] Brasil. Ministério da Saúde. Secretaria de Atenção à Saúde. Secretaria de Vigilância em Saúde. SB Brasil 2010: Pesquisa Nacional de Saúde Bucal: resultados principais / Ministério da Saúde. Secretaria de Atenção à Saúde. Secretaria de Vigilância em Saúde. - Brasília: Ministério da Saúde, 116p, 2012.

[17] Lima, J. E. O. Cárie dentária: um novo conceito. $R$ Dental Press Ortodon Ortop Facial, v. 12, n. 6, p. 119-130, 2007.

[18] Newbrun, E. Cariology. $2^{\mathrm{a}}$ ed. Baltimore: Williams \& Wilkins, 1983.

[19] Buss, P. M., Pellegrini Filho, A. A Saúde e seus Determinantes Sociais. Rev. Saúde Coletiva, v. 17, n. 1, p. 77-93, 2007.

[20] Ferreira, N. P.; Pereira, A. C. Aspectos preventivos da cárie e da fluorose dentária. In: Kriger, L., Mousés, S. J., Moysés, S. T. (Org). Saúde coletiva: métodos preventivos para doenças bucais. São Paulo: Artes Médicas, 2013, Cap. 2, p. 23-44.

[21] Leites, A. C. B. R., Pinto, M. B.; Sousa, E. R. Aspectos microbiológicos da cárie dental. Salusvita, v. 25, n. 2, p. 239- 252, 2006.

[22] Bussadori, C. M. Avaliação de enxaguatórios bucais na atividade biológica do biofilme formado em braquetes ortodônticos. Dissertação de Mestrado. Programa de Pós-Graduação Interunidades Bioengenharia - Escola de Engenharia de São Carlos; Faculdade de Medicina de Ribeirão Preto; Instituto de Química de São Carlos, da Universidade de São Paulo, 2013. São Carlos, 94f, 2013.

[23] Bönecker, M. Cárie dentária: um enfoque epidemiológico. In: BÖNECKER, M.; SHEIHAM, A. (Org). Promovendo saúde bucal na infância e adolescência: Conhecimentos e práticas. São Paulo: Editora Santos, 2004, Cap. 1, p. 14-28.

[24] Ramandan, Y. H., Koltermann, A. P., Piovesan, C. Cárie dentária em crianças brasileiras: Tendência e polarização. Disciplinarum Scientia. v. 15, n. 1, p. 137-146, 2014.

[25] CNDSS - Comissão Nacional sobre Determinantes Sociais da Saúde. As causas sociais das iniquidades em saúde no Brasil. Rio de Janeiro: Fiocruz; 2008. Disponível em: http://bvsms.saude.gov.br/bvs/publicacoes/causas_sociais_iniquidades .pdf. Acessado em 20 de agosto de 2019.

[26] Roncalli, A. G., Côrtes, M. I. S., Peres, K. G. Perfis epidemiológicos de saúde bucal no Brasil e os modelos de vigilância. Cad. Saúde Pública, v. 28, n. Sup 1, p.S58-S68, 2012.

[27] Costa, S. M., Abreu, M. H. N. G., Vasconcelos, M., Lima, R. C. G. S., Verdi, M., Ferreira, E. F. Desigualdades na distribuição da cárie dentária no Brasil: uma abordagem bioética. Ciência \& Saúde Coletiva, v. 18, n. 2, p. 461-470, 2013.

[28] Roncalli, A. G., Souza, T. M. S. Levantamentos epidemiológicos em saúde bucal no Brasil. In: Antunes, J. L. F., Peres, M. A (Org.). Epidemiologia de saúde bucal - 2. Ed. São Paulo: Santos, 2018, Cap. 3, p. 51-69.

[29] Cury, J. A., Tenuta, L. M. A. How to Maintain a Cariostatic Fluoride Concentration in the Oral Environment. Advances in Dental Research, v.20, p. 13-16, 2008.

[30] Cury, J. A., Oliveira, B. H., Santos, A. P. P., Tenuta, L. M. A. Are fluoride releasing dental materials clinically effective on caries control? Dental Materials, v. 32, p. 323-333, 2016.

[31] Chaves, S. C. L. Política de Saúde Bucal no Brasil: teoria e prática. 1. ed. Salvador: Editora da Universidade Federal da Bahia, 2016. 377p.

[32] Cury, J. A., Caldarelli, P. G., Tenuta, L. M. A. Necessidade de revisão da regulamentação brasileira sobre dentifrícios fluoretados. Rev Saúde Pública, v. 49, n. 74, p.1-7, 2015.

[33] Caldarelli, P. G., Lucas, B. B.; Silva, B. S. Contribuição da água e dentifrício fluoretado na prevalência de cárie e fluorose dentária: uma abordagem baseada em evidências. J Health Sci Inst., v. 34, n. 2, p.117-22, 2016.
[34] Brasil. Fundação Nacional de Saúde. Manual de fluoretação da água para consumo humano. Fundação Nacional de Saúde. - Brasília: Funasa, 72p, 2012.

[35] Tenuta, L. A., Cury, J. A. Fluoreto: da ciência à prática clínica. In: Assed S. (Org.). Bases científicas para a prática clínica. São Paulo: Artes Médicas, 2005, Cap. 4, p. 113-152.

[36] Roncalli, A. G., Noro, L. R. A., Cury, J. A.; Zilbovicius, C., Pinheiro, H. H. C., Ely, H. C., Narvai, P. C., Frazão, P. Fluoretação da água no Brasil: distribuição regional e acurácia das informações sobre vigilância em municípios com mais de 50 mil habitantes. Cad. Saúde Pública. v. 35, n. 6, p. 1-12, 2019.

[37] Freitas, C. H. S. M.; Sampaio, F. C., Roncalli, A. G., Moysés, S. J. Reflexões metodológicas sobre prevalência da fluorose dentária nos inquéritos de saúde bucal. Rev Saúde Pública, v. 47, n. Supl 3, p. 138 47, 2013.

[38] Frazão, P., Narvai, P.C. Cobertura e vigilância da fluoretação da água no Brasil: municípios com mais de 50 mil habitantes. 1. ed. São Paulo: Faculdade de Saúde Pública da USP, 207p, 2017.

[39] Pinheiro, H. H. C., Rabelo, M. A. B., Vieira, J. N. R., Castro, P. G. D. F., Lacerda, A. P. A. G., Souza, M. S., Cury, J. A., Narvai, P. C. Cobertura e vigilância da fluoretação das águas nos municípios com mais de 50 mil habitantes da região Norte. In: Frazão, P., Narvai, P. C. (Org.). Cobertura e vigilância da fluoretação da água no Brasil: municípios com mais de 50 mil habitantes. 1. ed. São Paulo: Faculdade de Saúde Pública da USP, 2017, Cap. 7, p. 112-130. 